\title{
Antioxidant Potential of Ocimum basilicum (Lamiaceae) Essential Oil as Preservation of the Physicochemical Properties of Palm Oil During One Month
}

\author{
Augustin Goudoum ${ }^{1, *}$, Ndomche Anne Makambeu ${ }^{1}$, Armand Abdou Bouba ${ }^{1}$, \\ Martin Benoît Ngassoum ${ }^{2}$, Carl Moses Mbofung ${ }^{3}$ \\ ${ }^{1}$ Department of Agriculture, Livestock and Derived Products, The Higher Institute of Sahel, The University of Maroua, Maroua, Cameroon \\ ${ }^{2}$ Department of Applied Chemistry, National High School of Agro Industrial Sciences, The University of Ngaoundere, Ngaoundere, \\ Cameroon \\ ${ }^{3}$ Department of Food and Bioresource Technology, School of Technology, The University of Bamenda, Bamenda, Cameroon
}

\section{Email address:}

goudoumaugust@gmail.com (A. Goudoum)

${ }^{*}$ Corresponding author

\section{To cite this article:}

Augustin Goudoum, Ndomche Anne Makambeu, Armand Abdou Bouba, Martin Benoît Ngassoum, Carl Moses Mbofung. Antioxidant Potential of Ocimum basilicum (Lamiaceae) Essential Oil as Preservation of the Physicochemical Properties of Palm Oil During One Month. International Journal of Nutrition and Food Sciences. Vol. 6, No. 4, 2017, pp. 181-186. doi: 10.11648/j.ijnfs.20170604.16

Received: May 24, 2017; Accepted: June 6, 2017; Published: July 13, 2017

\begin{abstract}
The present study aimed to determine ability of essential oil (EO) of Ocimum basilicum as protectant of stored crude palm oil (CPO) in Cameroon. Twenty nine constituents were identified representing over $95.9 \%$ of $O$. basilicum. The physicochemical properties of CPO sample change significantly $(\mathrm{p}<0.000)$ during storage period, except moisture content. When EO was added in this $\mathrm{CPO}$, there are not significant variations for this physicochemical porperties during storage period. The total phenol and $\beta$-carotene contents showed any significant variations during storage period for the formulation with the EO or citric acid. For concentrations of EO ranging from 1 to $10 \mathrm{mg} / \mathrm{L}$, the antioxidant activity rises from 23.07 to 92.20 and from 10.37 to $73.02 \%$ respectively for the first day and one month storage sample. $\mathrm{The}^{\mathrm{ET}} \mathrm{T}_{50}$ for conjugated dienes of CPO-EO vary from 6 days to 21 days at the concentrations going from $200 \mathrm{ppm}$ to $1000 \mathrm{ppm}$.
\end{abstract}

Keywords: Crude Palm Oil, Storage, O. basilicum, Physicochemical Properties

\section{Introduction}

In recent years, global demand for palm oil has increased significantly. This expansion is also due to increased consumption in emerging countries such as China, India and other Asian countries, where palm oil is mainly used as a frying oil [1]. The palm oil comes from mesocarp of the fruit of Elaesis guineensis when undergoes pressing procces. It contains more than $50 \%$ saturated fats and $40 \%$ unsaturated fats [2]. Crude Palm oil (CPO) and its derivatives are used $(80 \%)$ for human consumption [3]. During storage of CPO, degradations occur affecting the organoleptic and nutritional qualities. These deterioration depend on several factors such as presence of enzymes, temperature rise, light, presence of oxygen and the presence of metals [4] and microbial infestation before precessing [5].

However, previous studies tend to demonstrate that, the product obtained from the process contains several compounds such as carotenoids, tocopherols, vitamin E, sterols, phosphatides, triterpenes and aliphatic alcohols, phenolic and flavonoids [6]. The pronounced red color of the CPO is due to its particular richness in carotenoids [7]. The phenolic acids and flavonoids have antioxidant properties [8]. These antioxidant activity is influenced by position and degree of hydoxylation, polarity, solubility, and stability of the phenoxy radical [8].

Industrial palm oil production in Cameroon requires the addition of a chemical preservative so the citric acid is one of the most used. Citric acid was widely used in food industry. Tulin et al. [9] studies showed that liver of mice treated with citric acid has necrotic changes after injection during 10 days. Some countries like France describe synthetic citric 
acid as the most dangerous/cancerous additive and have given to E330 the title «E poison in food » [10].

Many researches done on natural products drifted of aromatic plants as alternative to the conventional additives for the control of food stability [11]. Essential oils of several plants have been used more widely as the alternative additives [12]. These plants are also used in traditional pharmacopoeia against some affections or for the cooking and for increasing the shelf life of food products [12]. Secondary metabilites is found in EO extract from aromatic plants. These essential oils, when they are used for the food protection, leave characteristic aromas of these plants. Theses aromas contain bioactive compounds that play many biological roles such as their antimicrobial effect, their antioxidant potential which can prevent the formation of free radicals by the oxidation of fatty acids within food on which they are applied [13]. Ocimum basilicum (Lamiaceae) is one of this aromatic plant which exhibited higher antixidant activity $[14,15,16]$. Data on the potential activities of EO to preseve CPO stay uncharted. In this work, the antioxidant properties of EO of O. basilicum to preserve physicochemical properties of CPO were studied.

\section{Materials and Methods}

\subsection{Chemicals and Instruments}

EO was obtained by the hydrodistillation of fresh leaves of $O$. basilicum collected from Maroua maket in Far-North Cameroon in January 2016.

CPO sample was colleted from the tank after delivery by a partnership instead. It is produced artisanally by small producers, with rudimenyary equipment. The CPO sample was stored at $27^{\circ} \mathrm{C}$ in small galvanized tank.

All reagents and solvents used were analytical grade.

Absorbance measurements were recorded by a PharmaSpec MODEL UV-1700 UV-Visible Reading spectrophotometer and Hitachi U-2001 UV-Invisible spectrophotometer using disposable and quartz cuvettes.

\subsection{Analysis of Chemical Composition of Ocimum basilicum Essential Oil}

The volatile components of $O$. basilicum were identified on the basis of GC/FID (Chromatograph Agilent HP-6820). The GC/FID was carried out with HP-5MS column (5\% phenyl methyl siloxane) with $30 \mathrm{~m}$ length and $250 \mu \mathrm{m}$ in diameter and $1 \mu \mathrm{m}$ of thickness. The oven temperature was programmed from $40^{\circ} \mathrm{C}$ to $230^{\circ} \mathrm{C}$ at $5^{\circ} \mathrm{C} / \mathrm{min}$ and the final temperature was held for $10 \mathrm{~min}$. Samples were injected with an autosampler. Individual compound identifications were made by matching spectra with those from reference data $[17,18]$.

\subsection{Physco-chemical Analysis of Crude Palm Oil and Formulation Crude Palm Oil-Essential Oil}

\subsubsection{Total Phenolics Content}

Total phenolics content was determined by the FolinCiocalteu method as modified by Gao et al. [19]. Total phenolics content was expressed as $\mathrm{mg}$ gallic acid equivalents (GAE)/g dry matter.

\subsection{2. $\beta$-carotene Amount}

The amount of $\beta$-carotene content in sample was determined according to Ainie et al. [20] method.

\subsubsection{Free Fatty Acid}

Estimation of the percentage free fatty acids as oleic acid was done, following the method of Pearson [21].

\subsubsection{Deterioration of Bleachability Index}

Deterioration of bleachability index (DOBI) was measured using the PORIM Test Methods [22].

\subsubsection{Moisture Content}

The moisture content was determined using AFNOR [23] method.

\subsubsection{Peroxide Value}

The peroxide value was determined using Aletor et al. [24] method.

\subsection{Antioxidant Activities of Crude Palm Oil and Formulation Crude Palm Oil-Essential Oil}

\subsection{1. $\beta$-Carotene-Linoleate Method}

The cooxidation of $\beta$-carotene of $\mathrm{CPO}$ in the presence of EO was evaluated by the $\beta$-carotene-linoleate model system [25]. Aliquots $(4.8 \mathrm{~mL})$ of this emulsion were transferred into different test tubes containing $0.2 \mathrm{~mL}$ of $\mathrm{CPO}$ or formulation CPO-EO at different concentration $\left(1,2,5\right.$ and $\left.10 \mathrm{mg} . \mathrm{L}^{-1}\right)$. After 2 hours, the absorbance was measured at $470 \mathrm{~nm}$, using a PharmaSpec MODEL UV-1700 spectrophotometer. Citric acid was used as positive control.

\subsubsection{DPPH Radical-Scavenging Activity}

The antioxidant activity of the CPO in the presence of EO, based on the scavenging activity of the stable 1,1-diphenyl-2picrylhydrazyl (DPPH) free radical, was determined by the method described by Braca et al. [26]. About $0.004 \% \mathrm{MeOH}$ solution of DPPH was prepared and $2 \mathrm{~mL}$ of the solution was added to $3 \mathrm{~mL}$ of the CPO, CPO-EO at different concentration $\left(1,2,5\right.$ and $\left.10 \mathrm{mg} . \mathrm{L}^{-1}\right)$. Citric acid was used for comparaison. Half an hour later, the absorbance at $517 \mathrm{~nm}$ was determined using a PharmaSpec MODEL UV-1700 spectrophotometer.

\subsubsection{Conjugated Dienes Method}

The amount of conjugated dienes was determined using Frankel et al. [27] method. Different quantity of EO (0.02, $0.04,0.8$ and $1 \mathrm{mg}$ ) were mixed with $20 \mathrm{mg}$ of CPO and $2 \mathrm{ml}$ of iso-octane. The mixture was placed in darkness at $50{ }^{\circ} \mathrm{C}$ to accelerate oxidation. After incubation, the absorbance of the mixture was measured every three days during four weeks at $234 \mathrm{~nm}$ against a blank in spectrophometer. The same experiment without EO were carried on $\mathrm{CPO}$ and $\mathrm{CPO}$-citric acid. The antioxidant was determined.

\subsection{Statistical Analysis}

Experimental results were expressed as means with standard deviation. Data were analyzed statistically by 
analysis of variance (ANOVA) $(\mathrm{p}<0.05)$ followed by the Duncan test, with the level of significance set at $5 \%$, with XLSTAT 2017 software. The $\mathrm{ET}_{50}$ were calculated from linear regression analysis using PROINRA 2.0 software.

\section{Result}

\subsection{Volatil Composition of Ocimum Basilicum Essential Oil}

The essential oil yield obtained for two days dried leaves is

Table 1. Chemical composition obtained by GC-FID of the crude essential oil of Ocimum basilicum leaves collected in the Far-North of Cameroon in January 2016 .

\begin{tabular}{|c|c|c|c|c|c|c|c|}
\hline $\mathbf{N}^{\circ}$ & KI* & Composés & $\%$ & $\mathbf{N}^{\circ}$ & KI* & Composés & $\%$ \\
\hline 1 & 926 & $\alpha$-thujene & 0.11 & 16 & 1169 & Terpine-4-ol & 2.01 \\
\hline 2 & 938 & $\alpha$-pinene & 0.35 & 17 & 1238 & Neral & 0.13 \\
\hline 3 & 947 & Camphene & 0.32 & 18 & 1288 & Thymol & 4.52 \\
\hline 4 & 970 & Sabinene & 0.21 & 19 & 1295 & Carvacrol & 1.47 \\
\hline 5 & 982 & $\beta$-pinene & 0.52 & 20 & 1352 & Eugenol & 2.86 \\
\hline 6 & 987 & Myrcene & 0.01 & 21 & 1357 & Farnesene & 3.02 \\
\hline 7 & 1013 & $\alpha$-terpinene & 0.91 & 22 & 1377 & $\alpha$-copaene & 1.65 \\
\hline 9 & 1028 & Limonene & 27.65 & 24 & 1422 & $\beta$-caryophyllene & 0.23 \\
\hline 10 & 1031 & $\beta$-phellandrene & 14.86 & 25 & 1455 & $\alpha$-humulene & 0.14 \\
\hline 11 & 1035 & 1,8-cineole & 0.1 & 26 & 1496 & Germacrene-D & 2.02 \\
\hline 12 & 1042 & 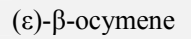 & 1.81 & 27 & 1518 & $(\varepsilon)$ - $\alpha$-bisabolene & 0.53 \\
\hline 13 & 1082 & Terpinolene & 0.21 & 28 & 1525 & $\delta$-cadinene & 1.04 \\
\hline 14 & 1085 & Fenchone & 0.25 & 29 & 1642 & Cardinol & 3.68 \\
\hline 15 & 1086 & Linalool & 21.51 & & & & \\
\hline
\end{tabular}

RI: Retention Index

* The compounds presented in this Table are those having a proportion higher or equal than $0.1 \%$.

\subsection{Physico-chemical Analysis of Crude Palm Oil and Formulation Crude Palm Oil-Essential Oil}

The results of some physicochemical properties during storage, total phenol $(\mathrm{mg} / 100 \mathrm{~g})$ and $\beta$-carotene contents present in CPO are presented in the Table 2.

This Table shows that physicochemical properties of CPO sample change significantly $(\mathrm{p}<0.000)$ during storage period,
$2.32 \pm 0.14 \%$. Twenty nine constituents were identified corresponding to $95.9 \%$ of $O$. basilicum essential oil with three major components: Limonene $(27.65 \%)$, linalool $(21.51 \%)$ and $\beta$-phellandrene $(14.86 \%)$ (Table 1). Monoterpenes hydrocabons was the predominant chemical group (46.8\%) in O. basilicum, followed by the oxygenated monoterpenes (31.91\%) and hydrocabons sesquiterpenes $(10.455 \%)$, while the oxygenated sesquiterpenes $(3.68 \%)$ had a minor share in the essential oil profile.

Table 2. Physicochemical qualities, total phenol and $\beta$-carotene contents of crude palm oil extracted traditionally and formulation crude palm oil and $O$. basilicum essential oil.

\begin{tabular}{|c|c|c|c|c|c|c|}
\hline & CPO & & CPO With EO & & CPO With C & cid \\
\hline Physicochemical proprties & First day & 4 weeks & First day & 4 weeks & First day & 4 weeks \\
\hline FFA (\%) & $6.85 \pm 0.05^{\mathrm{b}}$ & $7.73 \pm 0.03^{\mathrm{a}}$ & $4.95 \pm 0.03^{\mathrm{c}}$ & $5.00 \pm 0.05^{\mathrm{c}}$ & $3,93 \pm 0.02^{\mathrm{d}}$ & $4.00 \pm 0.02^{\mathrm{d}}$ \\
\hline DOBI & $1.95 \pm 0.03^{\mathrm{b}}$ & $1.85 \pm 0.04^{\mathrm{c}}$ & $2.02 \pm 0.01^{\mathrm{b}}$ & $2.01 \pm 0.01^{\mathrm{b}}$ & $2,27 \pm 0.05^{\mathrm{c}}$ & $2.23 \pm 0.04^{\mathrm{c}}$ \\
\hline PV (Meq Peroxide/kg) & $4.92 \pm 0.05^{\mathrm{b}}$ & $5.68 \pm 0.04^{\mathrm{a}}$ & $4.80 \pm 0.04^{\mathrm{b}}$ & $4.58 \pm 0.05^{\mathrm{b}}$ & $4,86 \pm 0.08^{b}$ & $4.46 \pm 0.06^{\mathrm{b}}$ \\
\hline MIV (\%) & $0.35 \pm 0.01^{\mathrm{a}}$ & $0.34 \pm 0.01^{\mathrm{a}}$ & $0.35 \pm 0.01^{\mathrm{a}}$ & $0.35 \pm 0.01^{\mathrm{a}}$ & $0,35 \pm 0.01^{\mathrm{a}}$ & $0.35 \pm 0.01^{\mathrm{a}}$ \\
\hline Total Phenol (mgGAE/100g) & $393.25 \pm 2.64^{\mathrm{a}}$ & $369.73 \pm 2.10^{\mathrm{b}}$ & $391.37 \pm 0.20^{\mathrm{a}}$ & $390.14 \pm 1.25^{\mathrm{a}}$ & $391,52 \pm 0.09^{\mathrm{a}}$ & $390.78 \pm 0.38^{\mathrm{a}}$ \\
\hline$\beta$-carotene content $(\mathrm{mg} / \mathrm{Kg})$ & $583.50 \pm 1.07^{\mathrm{a}}$ & $552.55 \pm 1.84^{\mathrm{b}}$ & $584.86 \pm 2.26^{\mathrm{a}}$ & $581.61 \pm 1.07^{\mathrm{a}}$ & $584,36 \pm 1.58^{\mathrm{a}}$ & $583.28 \pm 0.61^{\mathrm{a}}$ \\
\hline
\end{tabular}

Averages followed by the same letter in the same line are not different significantly with $\mathrm{P}<0.05$ (Test of Duncan).

FFA: Free Fatty Acid; DOBI: bleachability index; MIV: moisture contents; PV: Peroxide Values

The total phenol contents of CPO at the first day and after four weeks were different significantly $(\mathrm{p}<0.000)$ and were found to be $393.25 \pm 2.64$ and $369.73 \pm 2.10 \mathrm{mgGAE} / \mathrm{g}$ extract, respectively. With the EO or citric acid, the total phenol contents showed any significant differences during storage period. except moisture content. This physicochemical parameters of CPO was increased from 6.85 at 7.73 and from 4.95 at 5.68 respectivily for FFA and PV, and decreased from 1.95 at 1.85 for DOBI parameter within four weeks time. When EO was added for this CPO, there are not significant variations for this physicochemical porperties during storage period.
The carotene contents of CPO decreased significantly $(\mathrm{p}<$ 0.001 ) with the storage time from $583.50 \pm 1.07$ to $552.55 \pm 1.84$, respectivelty at the first day and after four weeks. There are not significant variations between both periods, when essential oil or citric acid are added in the CPO. 


\subsection{Antioxidant Activity}

Table 3. Antioxidant activity (\%) of CPO storage during four weeks with essential oil of O. basilicum in $\beta$-carotene-linoleate system.

\begin{tabular}{lcccccc}
\hline \multicolumn{7}{c}{ CPO with HE $(\mathbf{C}(\mathbf{m g} / \mathbf{L}))$} \\
\hline Analysis Time & CPO & $\mathbf{1}$ & $\mathbf{2}$ & $\mathbf{5}$ & $\mathbf{1 0}$ & CPO with Citric acid \\
\hline First day & $13.39 \pm 0.66^{\mathrm{d}}$ & $23.07 \pm 0.54^{\mathrm{d}}$ & $42.46 \pm 0.97^{\mathrm{c}}$ & $73.62 \pm 1.27^{\mathrm{b}}$ & $87.85 \pm 1.97^{\mathrm{a}}$ & $96.05 \pm 0.28$ \\
A week & $9.04 \pm 0.40^{\mathrm{e}}$ & $18.07 \pm 0.54^{\mathrm{d}}$ & $37.94 \pm 0.45^{\mathrm{c}}$ & $67.30 \pm 2.04^{\mathrm{b}}$ & $81.20 \pm 0.49^{\mathrm{a}}$ & \\
2 weeks & $6.30 \pm 0.54^{\mathrm{e}}$ & $16.35 \pm 0.77^{\mathrm{d}}$ & $32.10 \pm 1.48^{\mathrm{c}}$ & $53.64 \pm 0.93^{\mathrm{b}}$ & $72.55 \pm 0.99^{\mathrm{a}}$ & \\
4 weeks & $4.02 \pm 1.22^{\mathrm{e}}$ & $12.57 \pm 0.68^{\mathrm{d}}$ & $28.80 \pm 1.35^{\mathrm{c}}$ & $46.72 \pm 1.28^{\mathrm{b}}$ & $63.01 \pm 0.33^{\mathrm{a}}$ & $95.87 \pm 0.42$ \\
\hline
\end{tabular}

Averages followed by the same letter in the same line are not different significantly with $\mathrm{P}<0.05$ (Test of Duncan).

The results of Table 3,4 and 5 shows the antioxidant activity of $\mathrm{CPO}$ storage during four weeks with $\mathrm{EO}$ of $O$. basilicum. CPO sample without EO has the lower antioxidant activity at the first day of storage (13.39\%) which significantly $(\mathrm{p}<0.001)$ decreased with storage time $(4.02 \%$ after four weeks). The addition of EO of $O$. basilicum to
$\mathrm{CPO}$ at different concentrations prevented significantly $(p<0.001)$ the bleaching of $\beta$-carotene (Table 3). For concentrations of EO ranging from 1 to $10 \mathrm{mg} / \mathrm{L}$, the antioxidant activity increases from 23.07 to 87.85 and to 12.57 to $63.01 \%$ respectively for the first day sample and those storage during one month.

Table 4. Antioxidant activity (\%) of CPO storage during one month with essential oil of $O$. basilicum using DPPH system.

\begin{tabular}{lcccccc}
\hline \multicolumn{7}{c}{ CPO with HE $(\mathbf{C}(\mathbf{m g} / \mathbf{L}))$} \\
\hline Analysis Time & CPO & $\mathbf{1}$ & $\mathbf{2}$ & $\mathbf{5}$ & $\mathbf{1 0}$ & CPO Citric acid \\
\hline First day & $15.86 \pm 0.93^{\mathrm{e}}$ & $27.35 \pm 0.70^{\mathrm{d}}$ & $46.43 \pm 0.88^{\mathrm{c}}$ & $71.19 \pm 0.47^{\mathrm{b}}$ & $92.20 \pm 0.92^{\mathrm{a}}$ & $95.86 \pm 0.87$ \\
A week & $13.13 \pm 1.31^{\mathrm{e}}$ & $23.00 \pm 0.77^{\mathrm{d}}$ & $41.06 \pm 0.28^{\mathrm{c}}$ & $66.50 \pm 0.77^{\mathrm{b}}$ & $85.03 \pm 0.54^{\mathrm{a}}$ & \\
2 weeks & $10.95 \pm 0.14^{\mathrm{e}}$ & $20.22 \pm 0.76^{\mathrm{d}}$ & $36.58 \pm 0.67^{\mathrm{c}}$ & $60.15 \pm 0.98^{\mathrm{b}}$ & $79.98 \pm 0.18^{\mathrm{a}}$ & \\
4 weeks & $7.48 \pm 1.46^{\mathrm{e}}$ & $17.75 \pm 0.36^{\mathrm{d}}$ & $30.25 \pm 0.85^{\mathrm{c}}$ & $54.47 \pm 0.83^{\mathrm{b}}$ & $73.02 \pm 0.90^{\mathrm{a}}$ & \\
\hline
\end{tabular}

Averages followed by the same letter in the same line are not different significantly with $\mathrm{P}<0.05$ (Test of Duncan).

The Table 4 showed that all sample of $\mathrm{CPO}$ used in this study were able of scavenging DPPH free radicals. The CPO without EO and citric acid inhibit $15.86 \%$ of DPPH free radical contained in the solution at the first day. After one month storage this antioxidant activity decreased at $7.48 \%$. With EO added, CPO showed a significant variations $(\mathrm{p}<$ 0.001 ) concentration-dependent antiradical activity by inhibiting from $27.35 \%$ to $92.20 \%$ and from $17.75 \%$ to $73.02 \%$ DPPH free radical at the concentration range from 1 to $10 \mathrm{mg} / \mathrm{L}$, respectively at the first and four weeks storage. No significant different was observed between the antioxidant activity of citric acid at the first to last day of conservation. The CPO and formulation CPO-EO showed the weak activity compared to citric acid a known antioxidant product used in $\mathrm{CPO}$ in Cameroon.

Using the conjugated diene method, the storage $\mathrm{CPO}$ with EO of $O$. basilicum showed an antioxydant activity which depend to concentraion of EO and storage time (Table 5). At $50{ }^{\circ} \mathrm{C}, \mathrm{CPO}, \mathrm{CPO}-\mathrm{EO}$, and $\mathrm{CPO}-\mathrm{citric}$ acid were prooxidant and increased the formation of hydroperoxide from $200 \mathrm{ppm}$ to $1000 \mathrm{ppm}$ during storage time. The CPO sample upgraded hydroperoxide formation, with an $\mathrm{ET}_{50}$ corresponding to 3 days 23 hours and 38.07 minutes. The $\mathrm{ET}_{50}$ of formulation CPO-EO vary from 6 days to 21 days at the concentrations going from $200 \mathrm{ppm}$ to $1000 \mathrm{ppm}$. Formulation with citric acid which is the control, had lower prooxidant activity $\left(\mathrm{ET}_{50}=28\right.$ days $)$ than the formulation of CPO-EO at 1000 ppm.

Table 5. $E T_{50}$ values (days) of crude palm oil storage during four weeks with essential oil of $O$. basilicum leaves from conjugated dienes method.

\begin{tabular}{llll}
\hline & ET $_{\mathbf{5 0}}$ & & \\
\hline & CPO & CPO with HE & CPO with Critic acid \\
\cline { 1 - 2 } Concentrations & $3 \mathrm{~d} 23 \mathrm{~h} 38.07 \mathrm{mn}$ & $28 \mathrm{j} 21 \mathrm{~h} 52.5 \mathrm{mn}$ \\
\hline $200 \mathrm{ppm}$ & & $6 \mathrm{~d} 21 \mathrm{~h} 18.3 \mathrm{mn}$ & \\
$400 \mathrm{ppm}$ & & $11 \mathrm{~d} 18 \mathrm{~h} 12.2 \mathrm{mn}$ & \\
$800 \mathrm{ppm}$ & & $17 \mathrm{~d} 11 \mathrm{~h} 28.3 \mathrm{mn}$ & \\
$1000 \mathrm{ppm}$ & & $21 \mathrm{jd} 3 \mathrm{~h} 41.5 \mathrm{mn}$ & \\
\hline
\end{tabular}

D: days; h: hour; mn: minutes.

\section{Discussion}

The physicochemical properties of samples increased when $\mathrm{CPO}$ is storage for four weeks. During storage, edible oils undergo physical and chemical changes due to several factors such as light, high temperatures, traces of metals, water and miroorganisms $[28,29]$. The common pathways of degradation are isomerization, oxidation and hydrolysation. 
Light, enzymes, pro-oxidant metals in the presence of unsaturated lipids, induce oxidation [28]. These reactions therefore lead to a decrease in DOBI and an increase in acidity [13]. During storage there is a gradual accumulation of oxidation products, which tends to reduce the melting point and increase the peroxide value of stored oils [30].

When essential oil of $O$. basilicum was added to CPO, the variation between physicochemical parameter was not significant. This non signification variation of physicochemical parameters was due to actives compounds of these essential oil wich protect foods against pathogenic and spoilage microorganisms [12]. Sienkiewicz et al. [31] shown that, $O$. basilicum essential oil was more active against microorganisms. These antimicrobial activity may be an important factor for stablity of study CPO. When EO was added to a food product, it is enclose into nanoemulsions, and stability of volatile components increases for the long time effect on microorganisms [32]. Udensi and Irorgbu [2] report that low levels of carotene in the oil sample indicate low levels in vitamin $\mathrm{A}$, and consequently indicates a long storage period of the oil sample.

The study CPO sample possessed higher total phenolic contents. Phenolic compounds play antioxidant ruler which act as free radical terminators and reduced oxidative degradation of lipids [33, 34]. Bouhdid et al. [35] shown that essential oils rich in thymol, borneol, carvacrol, cymene and terpinolene inhibit more than $74.5 \%$ oxidation of linoleic acid. The reductive activity of the DPPH radical $O$. basilicum EO was due to the phenolic compounds and non-phenolics such as linalool, as shown by Judic and Milos [36] and Zohra [37].

According to their compounds, essential oils have several modes of actions as antioxidant, such as prevention of chain initiation, free radical scavengers, reducing agents, termination of peroxides, prevention of continued hydrogen abstraction as well as quenchers of singlet oxygen formation and binding of transition metal ion catalysts $[11,38]$. In our present study, EO of $O$. basilicum was antioxidant in $\mathrm{CPO}$ and strongly reduce peroxides formation.

\section{Conclusion}

EO of $O$. basilicum leaves has an antioxidant activity which preserves physicochemical properties of the CPO from degradation during one month of exposure. This antioxidant activity, although below that of citric acid, may be useful in the conservation of vegetable oils intended for human consumption.

\section{References}

[1] A. Rossignol-Castera, J-L. Coustille, S. Mazette, and I. Bouvarel, "Etude de la composition et de la qualité des huiles acides industrielles en vue d'une meilleure connaissance de leur valeur nutritionnelle", Sixièmes Journées de la Recherche Avicole, St Malo, 30 et 31 mars 2005.

[2] E. A. Udensi, and F. C. Iroegbu, "Quality assessment of palm oil sold in major markets in Abia State, Nigeria", Agro-
Science, vol. 6 (2), 25-27, 2007.

[3] S. A. Fatin, S. Rosnah, and Y. Robiah, "The Effect of Storage Time of Chopped Oil Palm Fruit Bunches on the Palm Oil Quality. "ST26943"”, 2nd International Conference on Agricultural and Food Engineering, CAFEi2014". Agric. Sci. Procedia, vol. 2, pp. 165-172, 2014.

[4] G. F. Ngando-Ebongue, E. A. Mpondo-Mpondo, and M. A. Ewane, "Some quality parameters of crude palm oil from major markets of Douala, Cameroon", Afr. J. Food Sci. Vol. 7 (12), pp. 473-478, 2013.

[5] E. I. Ohimain, S. C. Izah, and S. O. Abah, "Air quality impacts of smallholder oil palm processing in Nigeria", J. Environ. Protection, vol. 4, pp. 83-98, 2013.

[6] B. M. Z. Rohani, "Process design in degumming and bleaching of palm oil", universiti teknologi malaysia, Research Note 74198, pp. 14-43, 2006.

[7] M. M. Haswani, A. Noriham, and M. N. Zainon, "Total phenolic content and antioxidant activities of palm puree prepared from various tenera varieties", $2^{\text {nd }}$ International Conference on Biotechnology and Fodd Science, Press, Singapore, vol. 7, pp. 23-26. 2011.

[8] K. Sundram, R. Sambanthamurthi, and Y. A. Tan, "Palm fruit chemistry and nutrition", Asia Pac. J. Clin. Nutr. vol. 12 (3), pp. 355-362, 2003.

[9] A. Tulin, K. Ayflegül, B. Elvan, and K. Hamiyet, "The shortterm effects of single toxic dose of citric acid in mice", J. Cell. Mol. Biol. vol. 2, pp. 19-23, 2003.

[10] P. A. Boga, U. S. Binokay, K. Akallioglu, and Y. Sertdemir, "Evaluation of E330-induced developmental toxicity using FETAX”, Turk. J. Biol. vol. 37, pp. 265-272, 2013.

[11] A. Goudoum, A. B. bdou, T. L. S. Ngamo, M. B. Ngassoum, and C. M. Mbofung, "Antioxidant activities of essential oil of Bidens pilosa (Linn. Var. Radita) used for the preservation of food qualities in North Cameroon", Food Sci Nutr., 2016. doi: $10.1002 /$ fsn 3.330 .

[12] P. Tongnuanchan, and S. Benjakul, "Essential Oils: extraction, bioactivities, and their uses for food preservation", J. Food Sci. vol. 79 (7), pp. 1231 - 1249, 2014

[13] A. Goudoum, T. L. S. Ngamo, M. B. Ngassoum, and C. M. Mbofung, "Antioxidant activities of essential oils of Clausena anisata (Rutaceae) and Plectranthus glandulosus (Labiateae) plants used against stored grains insects in North Cameroon", Inter. J. Biol. Chem. vol. 3, pp. 567-577, 2009.

[14] D. Benedec, L. Vlase, D. Hanganu, and I. Oniga, "Antioxidant potential and polyphenolic content of romanian Ocimum basilicum”, Dig. J. Nanomater. Biostruct., vol. 7 (3), pp. 1263 $-1270,2012$.

[15] L. H. Khelifa, M. Brada, F. Brahmi, D. Achour, M. L. Fauconnier, and G. Lognay, "Chemical composition and antioxidant activity of essential oil of ocimum basilicum leaves from the northern region of algeria", Topclass Journal of Herbal Medicine, vol. 1 (2), 25-30, 2012.

[16] E. A. Uyoh, P. N. Chukwurah, A. D. Imabasi, and A. C. Bassey, "Evaluation of antioxidant capacity of two Ocimum species consumed locally as spices in Nigeria as a justification for increased domestication", Am. J. Plant Sci. vol. 4, pp. 221$229,2013$. 
[17] N. W. Davies, "Gas Chromatographic Retention Indices of Monoterpenes and Sesquiterpenes on Methyl Silicone and Carbowax 20M Phases", J. Chromatogr. vol. 503, 1-24, 1990.

[18] R. Kouroussou, T. Lanara, and S. Kokkini, "Piperitone oxiderich essential oils from Mentha longifolia subsp. petiolata and M. x villoso-nerveta grown on the Island of Crete (S Greece)", J. Essent. Oil Res. vol. 10, pp. 375-379, 1998.

[19] X. Gao, M. ohlander, N. Jeppsson, L. Björk, and V. Trajkovski, "Changes in antioxidant effects and their relationship to phytonutrienents in fruits of sea buckthorn (Hippophae rhamnoides L) during maturation", J. Agric. Food Chem. vol. 48, pp. 1485-1490, 2000.

[20] K. Ainie, S. W. Lin, A. I. Nor, Y. Mohtar, T. T. Sue, and A. I Nuzul, "Malaysian Palm oil board (MPOB) test methods: a compendium of test on palm oil products, palm kernel products, fatty acids, food related products and others", MPIB, pp 172-177, 2005.

[21] D. Pearson, "The Chemical Analysis of Foods", Churchill Living Stone, Edinburgh, London, pp. 121 - 150, 1976.

[22] H. N. Abdul, M. H. Ngo, Y. M. Choo, and A. N. Ma, "Dry Heating of Palm Fruits: Effect on Selected Parameters", Am. J. Eng. Appl. Sci., vol. 5 (2), pp. 128-131, 2012.

[23] AFNOR "Recueil de normes françaises. Corps gras, graines oléagineuses, produits dérivés", AFNOR, Paris (France), 2ème édition, 1981.

[24] V. A. Aletor, G. A. Ikhena, and V. Egharevba, "The quality of some locally processed Nigerian palm oil: An estimation of some critical variables", Food Chem. vol. 36, pp. $311-317$. 1990.

[25] H. E. Miller, "A simplified method for the evaluation of antioxidant”, J. Am. Oil Chem. Soc. vol. 18, pp. 439-452, 1971.

[26] A. Braca, N. D. Tommasi, L. D. Bari, C. Pizza, M. Politi, and I. Morelli, "Antioxidant principles from Bauhinia terapotensis", J. Natural Products. vol. 64, pp. 892-895, 2001.

[27] E. N. Frankel, S. W. Huang, J. Kanner, and J. B. German, "Interfacial phenomena in the evaluation of antioxidants: bulk oils versus emulsions", J. Agric. Food Chem. vol. 42, pp. 1054-1059, 1994.

[28] A. V. Y. Barku, H. D. Nyarko, and P. Dordunu, "Studies on the physicochemical characteristics, microbial load and storage stability of oil from indian almond nut (Terminalia catappal) ", Food Sci. Qual. Management vol. 8 (1), pp. 9-17, 2012.

[29] A. Goudoum, N. A. Makambeu, A. B. Abdou, and C. M. Mbofung, "Some Physicochemical Characteristics and Storage Stability of Crude Palm Oils (Elaeis guineensis Jacq) ", A. J. F. S. T. vol. 3 (4), pp. 97-102, 2015.

[30] C. P. Tan, and Y. B. Che Man, "Quantitative differential scanning calorimetric analysis for determining total polar compounds in heated oils", J. A. O. C. S. vol. 76, pp. 10471057,1999

[31] M. Sienkiewicz, M. Lysakowska, M. Pastuszka, W. Bienias, and E. Kowalczyk, "The potential of use basil and rosemary essential oils as effective antibacterial agents", Molecules vol. 18, pp. 9334-9351, 2013.

[32] M. Hyldgaard, T. Mygind, and R. L. Meyer, "Essential oils in food preservation: mode of action, synergies, and interactions with food matrix components", Frontiers Microbiol. vol 3, pp. $1-24,2012$.

[33] O. A. Odukoya, M. O. Jenkins, O. O. Ilori, and M. O. Sofidiya, "The use of selected Nigerian natural products in management of environmentally induced skin damage", Pak. J. Biol. Sci. vol. 8, pp. 1074-1077, 2005.

[34] F. Pourmorad, S. J. Hosseinimehr, and N. Shahabimajd, "Antioxidant activity, phenol and flovonoids content of some selected Iranian plants", Afr. J. Biotech. vol. 5, pp. 1142-1145, 2006.

[35] S. Bouhdid, M. Idaomar, A. Zhiri, D. Baudoux, N. S. Skali, and J. Abrini, "Thymus essential oils: chemical composition and in vitro antioxidant and antibacterial activities", International Congress of Biochimistry, Agardir, 09-12 mai 2006.

[36] M. Jukic, and M. Milos, "Catalytic oxydation and antioxydant properties of thyme essential oils", Croatica Chemica Acta, vol. 78 (1), pp. 105-110, 2005.

[37] M. Zohra, "Etude du pouvoir antimicrobien et antioxydant des huiles essentielles et flavonoïdes de quelques plantes de la région Tlemcen", Thèse de Magistère en Biologie, Université Abou Bakr Belkaïd Tlemcen (Algérie), 144 p, 2006.

[38] L.-C. Mao, X. Pan, F. Que, and X.-H. Fang, "Antioxidant properties of water and ethanol extracts from hot air-dried and freeze-dried daylily flowers", Eur. Food Res. Technol. vol. 222, pp. 236-41, 2006. 